\title{
Entrepreneurial Orientation and Business Internationalisation Process: The Theoretical Foundations of International Entrepreneurship
}

\author{
Krzysztof Wach
}

\begin{tabular}{|c|c|}
\hline & A B S T R A C T \\
\hline $\begin{array}{l}\text { Objective: } \mathrm{Tr} \\
\text { international }\end{array}$ & $\begin{array}{l}\text { main goal of the article is to discuss and elaborate on the basics of } \\
\text { trepreneurial orientation (IEO), its fundamentals and principles. }\end{array}$ \\
\hline $\begin{array}{l}\text { Research Des } \\
\text { trying to link } \\
\text { character, thi }\end{array}$ & $\begin{array}{l}\text { \& Methods: The paper reviews these three important terms by } \\
\text { em and suggests a holistic framework. The article is of descriptive } \\
\text { t is based on literature review and its constructive critics. }\end{array}$ \\
\hline $\begin{array}{l}\text { Findings: Fir } \\
\text { international } \\
\text { conceptualisa } \\
\text { dimensional } \\
\text { perspective o }\end{array}$ & $\begin{array}{l}\text { international entrepreneurial process was discussed from the } \\
\text { ntrepreneurship perspective. Secondly, the paper introduces the } \\
\text { in of entrepreneurial orientation from both three- and multi- } \\
\text { spectives. Thirdly, IEO is conceptualised and operationalised from the } \\
\text { ntrepreneurial internationalisation of firms. }\end{array}$ \\
\hline $\begin{array}{l}\text { Implications } \\
\text { considered b } \\
\text { identify and } \\
\text { proactivenes }\end{array}$ & $\begin{array}{l}\text { Recommendations: IEO is a multi-dimensional concept. IEO can be } \\
\text { an individual and firm-level construct. IEO enables business to } \\
\text { loit internationalisation opportunities. IEO reflects the firms overall } \\
\text { ad aggressiveness in its pursuit of international markets. }\end{array}$ \\
\hline $\begin{array}{l}\text { Contribution } \\
\text { international } \\
\text { one of the } \mathrm{m} \\
\text { entrepreneur } \\
\text { (IE). }\end{array}$ & $\begin{array}{l}\text { Value Added: The article is an attempted synthesis of the concept of } \\
\text { trepreneurial orientation. It focuses on IEO as the implementation of } \\
\text { important research theme in the theory of entrepreneurship, which is } \\
\text { orientation (EO) into the studies of international entrepreneurship }\end{array}$ \\
\hline Article type: & conceptual article \\
\hline Keywords: & $\begin{array}{l}\text { international entrepreneurship; entrepreneurial orientation; } \\
\text { international entrepreneurial orientation; entrepreneurship; } \\
\text { business internationalisation; entrepreneurial process }\end{array}$ \\
\hline JEL codes: & $\mathrm{F} 23, \mathrm{O} 30, \mathrm{M} 16$ \\
\hline Received: $2 \mathrm{~F}$ & Accepted: 22 May 2015 \\
\hline
\end{tabular}

Suggested citation:

Wach, K. (2015). Entrepreneurial Orientation and Business Internationalisation Process: The Theoretical Foundations of International Entrepreneurship. Entrepreneurial Business and Economics Review, 3(2), 9-24. doi: 10.15678/EBER.2015.030202 


\section{INTRODUCTION}

This article focuses on entrepreneurial orientation during the internationalisation process of the firm, which is one of the main research streams within international entrepreneurship, that applies entrepreneurship theory within international business studies. While internationalisation generally refers to any type of cross-border activities of firms (Wach, 2014a; Autio, Sapienza \& Almeida, 2000) and entrepreneurship is about "identification and exploitation of entrepreneurial opportunities" focusing on innovation, novelty and value creation (Volkmann et al., 2010, p. 4), thus international entrepreneurship has been conceptualised as "the discovery, enactment, evaluation and exploitation of opportunities - across national borders - to create future goods and services" (Oviatt \& McDougall, 2005). Determinants and factors contributing to fostering and blooming of international entrepreneurship are varied and multifaceted. International entrepreneurial culture or international entrepreneurial orientation is a part of the multidimensional structure supporting and influencing international entrepreneurship from the cross-country and cross-culture perspective (Obloj, Weinstein \& Zhang, 2013; Claar et al., 2012; Wach, 2015).

The main goal of the article is to discuss and elaborate on the basics of international entrepreneurial orientation, its fundamentals and principles. The article is descriptive in character, thus it is based on literature review and its constructive critics.

\section{MATERIAL AND METHODS}

In recent decades, both the theory of internationalisation of the firm and/or the theory of international business have developed. Recent developments in international business studies prove that entrepreneurial orientation (EO) emerges as one of the important potential factors contributing to the intensification of the processes of internationalisation of the firm. Thus the notion of international entrepreneurship (IE) has been flourishing as well.

General theory of entrepreneurship indicates that market opportunities are a common and dominant link of all entrepreneurial activities. Entrepreneurship theory refers to the identification or creation opportunities, their evaluation and exploitation. The expansion into new geographic markets is undoubtedly an important market opportunity for growth and development. The internationalisation as a response to the market opportunity takes diverse paths. Based on the in-depth literature search, this study aims to determine whether, why and how, in the context of diverse environmental conditions, the pursuit of market opportunities contributes to increasing the internationalisation of firms.

In its main objective, the article focuses on the presentation, discussion and elaboration on the basics of international entrepreneurial orientation, its fundamentals and principles.

Smooth and efficient conducting of scientific research requires a procedure according to pre-determined steps in order to obtain the most valuable cognitive effects of the research process (Babbie, 2012, pp. 112-113). The nature of the research project is multidimensional, it realises exploratory, descriptive, analytical and predictive purposes 
(Collis \& Hussey, 2009, p. 5). The thorough literature study was prepared in order to conceptualise and operationalise the research project. Therefore, the main research method was literature review and its constructive critics. Five-stages model of a critical literature review proposed by Fisher (2010) was applied in this study (Figure 1).
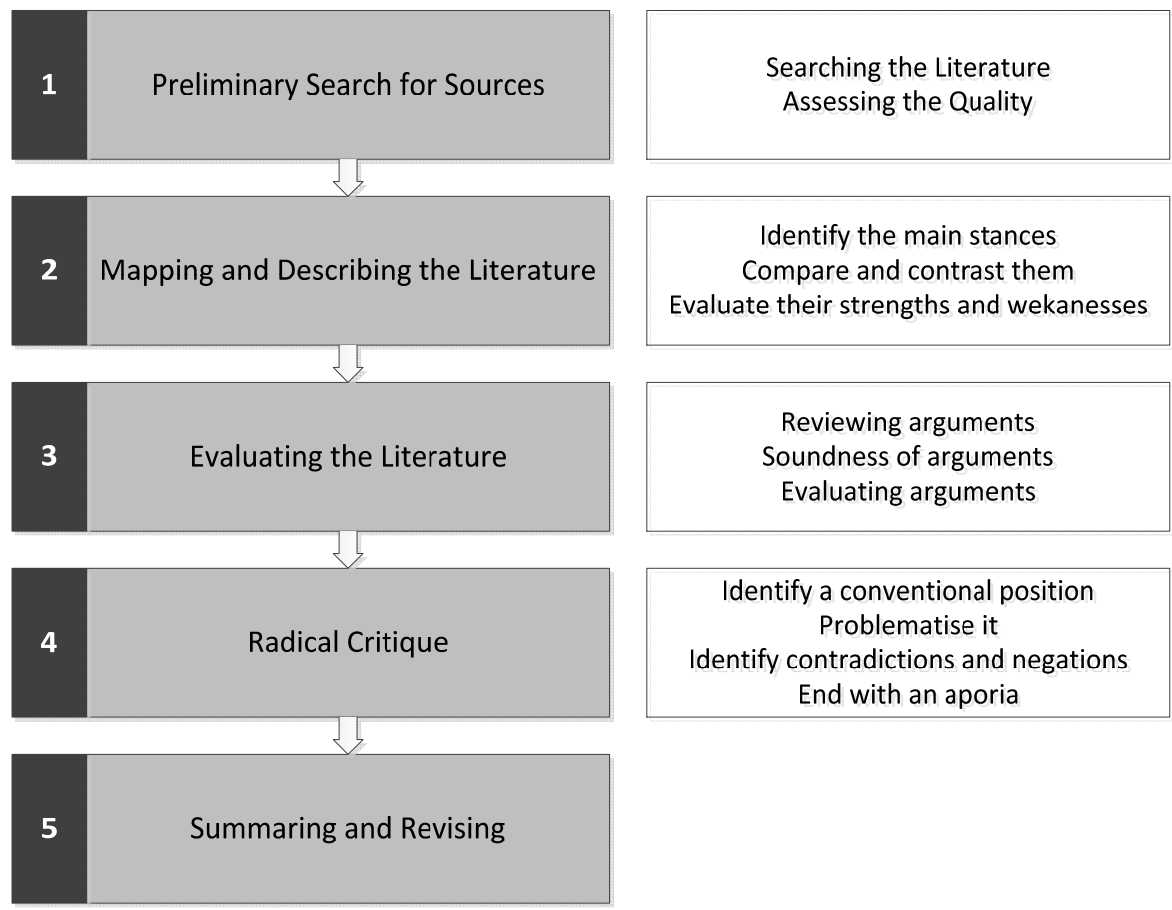

Identify a conventional position

Problematise it

Identify contradictions and negations

End with an aporia

Figure 1. Methodological process of a critical literature review Source: own study based on Fisher et al. (2010, pp. 94-130).

The preliminary literature review and the established objectives of this study, led to prepare the conceptual framework of the research project based on a literature review with the line of deductive reasoning. This kind of the research model will include the deductive approach, making the whole study structure logical and resultative.

\section{LITERATURE REVIEW AND THEORY DEVELOPMENT}

\section{Entrepreneurial Process from the International Entrepreneurship Perspective}

International entrepreneurship (IE) has become a popular research field since its emergence in the late 1980s as well as its intensive and influential bloom in the mid1990s. Still a new research field, there is a lot of controversy over the delimitation of IE as well as serious disputes on whether IE is a separate discipline or not. International entrepreneurship "has become an important research domain at the intersection of entrepreneurship and international business" (McDougall-Covin et al., 2014, p. 2); however, it is influenced not only by business disciplines (economics, management), but 
also from non-business disciplines "as diverse as sociology, economic geography, political science, development economics, and psychology" (McDougall-Covin et al., 2014, p. 2).

International entrepreneurship (IE) specifically examines and prioritises the role of the entrepreneur as a key factor in the internationalisation process of the firm, especially SMEs (Daszkiewicz, 2014a; 2014b). IE describes internationalisation as a "combination of innovative, pro-active, and risk-seeking behavior that crosses national borders and is intended to create value in organizations" (McDougall \& Oviatt, 2000, p. 903).

As already mentioned, international entrepreneurship is reported to be a research domain at the intersection of two fields, namely entrepreneurship and international business (McDougall-Covin et al., 2014). Zucchella \& Sciabini (2007) add one more very important fundamental pillar, which is strategic management (Figure 2), however strategic management is included also in entrepreneurship (strategic entrepreneurship) as well as in international business (business strategy approach). Nevertheless, its rich productivity and influence can also be analysed separately.

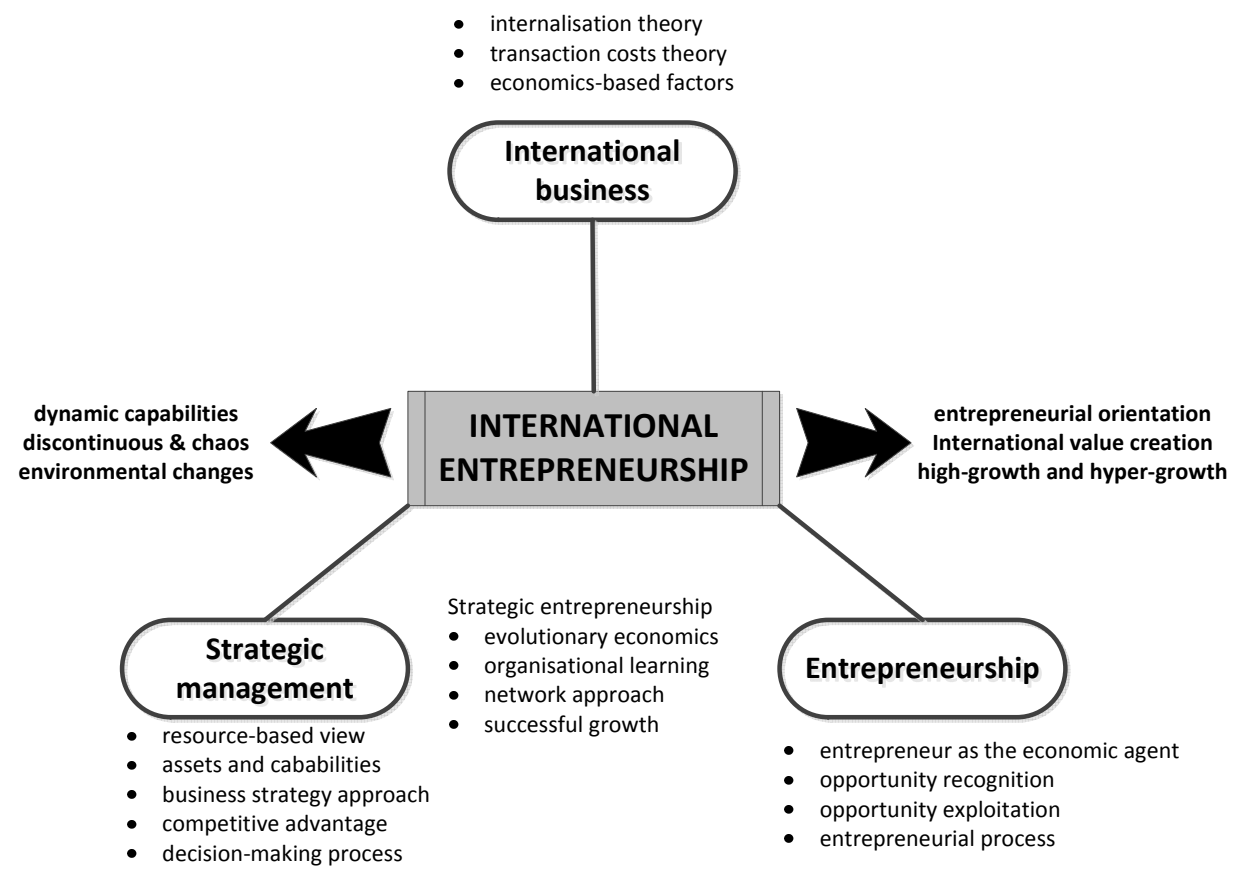

Figure 2. International entrepreneurship as the amalgamation of three fields

Source: adapted and extended from Zucchella \& Sciabini (2007, p. 22).

International entrepreneurship can be treated dichotomously: firstly, as a research area within the theory of entrepreneurship or the theory of internationalisation. Secondly, it can be considered an autonomous area of research. The latter trend is becoming more and more popular and quite widely accepted by international scholars, as is noticeable in top scientific journals publishing articles on IE, especially after 2010.

There are many ways in explaining internationalisation of firms in business studies, from both economics and management perspectives. It is necessary to distinguish six 
main research strands and their development from stages models to holistic approaches (Wach, 2012, p. 99):

- stages models (including innovation-related models),

- resource-based view,

- network approach,

- business strategy approach,

- international entrepreneurship approach,

- integrative approach (holistic models).

Taking into account the overall theory of economics in general, but especially the narrow understanding of international business, international entrepreneurship can be regarded only as one of the research approaches to the issues of internationalisation of a firm (Andersson \& Florén, 2008; Ruzzier et al., 2006). IE has made an important contribution to international business and to the theory of internationalisation of the firm. The rich heritage of this school fully justifies its distinction as a separate stream within the framework of internationalisation theory, firstly because of its important contribution and, secondly, by its nature, which puts the spotlight on SMEs.

In a broad understanding, international entrepreneurship includes at least two different research areas (Wach, 2014b, p.434):

- creative process of recognition and exploitation of opportunities in foreign markets; in this sense, this research area is the same as the traditional approach of the theory and practice of entrepreneurship, using the same analytical tools as in the case of establishment of domestic ventures; what is crucial, it is characterised by a high degree of creativity, innovation and entrepreneurship, and a special role in the internationalisation process is attributed to the entrepreneur (Figure 3),

- international studies and comparative research in the field of entrepreneurship; in this sense, this research area is the same as with traditional international comparative studies, placing entrepreneurship as the main subject of these comparative studies (e.g. GEM).

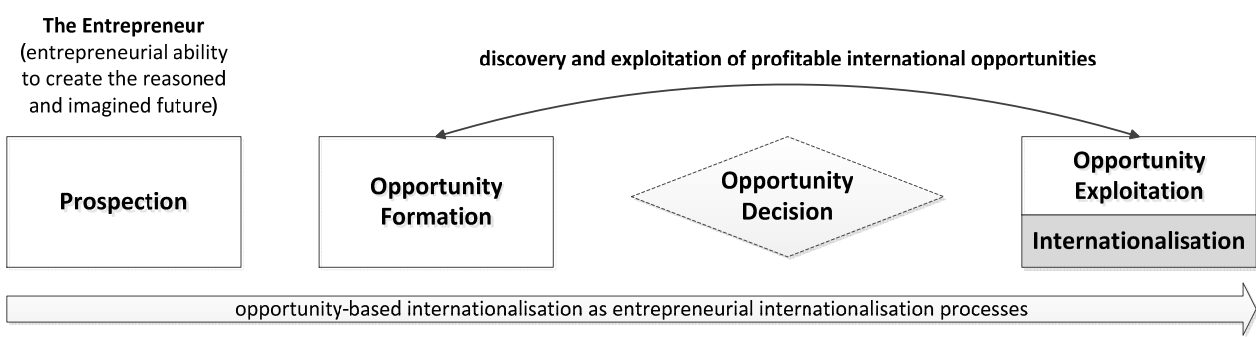

Figure 3. The internationalisation process in the international entrepreneurship Source: adapted and extended from Oyson \& Whittaker (2010, p. 9).

It can be noticed that international entrepreneurship theory focuses on three main research issues, which are (i) the entrepreneur, (ii) the external business environment and (iii) the entrepreneurial process (Coviello et al., 2011; Wach, 2012, p. 113). Zucchella \& Sciabini (2007) emphasize that IE develops the typical internationalisation process sequence starting from opportunities recognition and ending with corporate 
performance, in which resource mobilisation and dynamic capabilities play a major role (Figure 4). Internationalisation is a learning process of key employees based on opportunity recognition, opportunity seeking and opportunity taking (Zucchella \& Scabini, 2007).

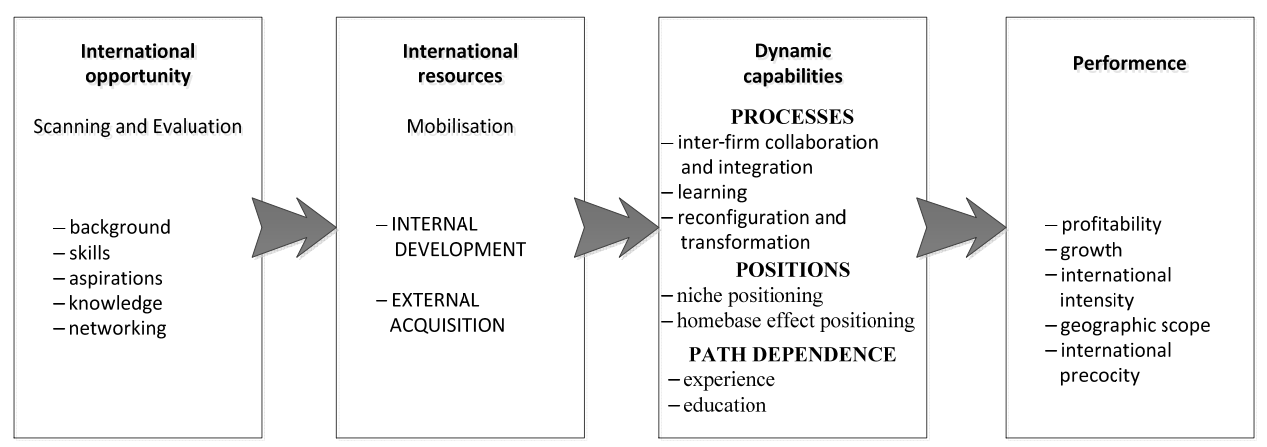

Figure 4. An interpretative model for international entrepreneurship

Source: Zucchella \& Sciabini (2007, p. 126).

The literature review and the above mentioned facts reveal that investigating the internationalisation process of firms from the perspective of entrepreneurship theory, in terms of making use of entrepreneurial and innovation processes (stimulating the firmlevel internationalisation), constitutes a new and blooming research domain for international entrepreneurship. It is crucial, form the perspective of entrepreneurship, to focus on entrepreneurial processes while studying business internationalisation.

\section{Conceptualisation of Entrepreneurial Orientation}

Entrepreneurship is an ambiguous and multi-faceted term (Gaweł, 2008, p. 21), however entrepreneurship in its broad sense is understood as entrepreneurial orientation (Gawet, 2013, p. 17), which first of all helps us to conceptualise entrepreneurship itself, and what is more it helps us also apply the theory of entrepreneurship in the internationalisation and business studies much easier. Żur and Wałęga (2015, p. 120) notice that two parallel terms coexist in academic writing regarding firm-level entrepreneurship, namely entrepreneurial orientation (EO) and corporate entrepreneurship (CE). Zahra (1996) as well as Dess and Lumpkin (2005) suggest that EO represents potential entrepreneurial intentions and attitudes of a firm, while CE represents actual entrepreneurial activities of a firm. Antoncic and Hisrich (2001) and many other authors believe that these two constructs complement each other.

There are many attempts to define EO, and various researchers offer their own insights on this issue, however they have one thing in common: they treat entrepreneurship as a firm-level phenomenon. Basso, Fayolle and Bouchard (2009) found that EO can be traced to the pioneering writings of Mintzberg (1973), Khandwalla (1976/1977), and Miller (1983).

Miller (1983) and later Covin and Slevin (1989) introduced a three-dimensional concept of EO (a composite construct), represented by such qualities as (i) proactive, (ii) innovative, and (iii) risk taking behaviours of a firm. Lumpkin and Dess (1996) proposed a 
Table 1. The Miller / Covin and Slein EO Scale (M/C\&S Scale) Innovativeness items

EO1: In general the top managers of my firm favour ....

... a strong emphasis on the marketing of 1234567 tried-and-true products and services.

... a strong emphasis on R\&D, technological leadership and innovations.

(Item originally proposed by Khandwalla [1976/977])

EO2: How many new lines of products or services has marketed in the past 5 years (or since its establishment)?

No new lines of products or services.

1234567 Very many new lines of products or services.

[Item originally proposed by Miller and Friesen (1982)]

EO3: Changes in products or services lines ...

...have been mostly of a minor nature. $\quad 1234567$...have usually been quite dramatic.

[Item originally proposed by Miller and Friesen (1982)]

\section{Proactiveness items}

EO4: In dealing with its competitors, my firm ...

...typically responds to actions that 1234567 ...typically initiate actions to which competitors initiate. competitors then respond.

[Item originally proposed by Covin and Slein (1989)]

EO5: In dealing with its competitors, my firm ...

...is very seldom the first business to 1234567 ...is very often the first business to introduce new products/services, administrative techniques, operating technologies, etc. introduce new products/services, administrative techniques, operating technologies, etc.

[Item originally proposed by Covin and Slein (1989)]

EO6: In dealing with its competitors, my firm ...

...typically seeks to avoid competitive 1234567 ...typically adopts a very competitive, clashes, performing a "live0an-let-live" "undo-the-competitors" posture.

posture.

(Item originally proposed by Covin and Slein [1989])

\section{Risk-taking items}

EO7: In general the top managers of my firm have ....

...a strong proclivity for low-risk projects 1234567 ...a strong proclivity for high-risk (with normal and certain rates of return). projects (with chances of very high returns).

[Item originally proposed by Khandwalla (1976/1977)]

EO8: In general the top managers of my firm believe that ....

...owing to the nature of the 1234567 ...owing to the nature of the environment, it is best to explore it gradually via cautious, incremental behaviour. environment, bold wide-ranging acts are necessary to achieve the firm's objective.

[Item originally proposed by Miller and Friesen (1982)]

EO9: When confronted with decision-making situations involving uncertainty, my firm ...

...typically adopts a cautious "wait-and- 1234567 ...typically adopts a bold aggressive see" posture in order to minimalize the posture in order to maximize the probability of making costly decisions. probability of exploiting potential opportunities.

[Item originally proposed by Covin and Slein (1989)] 
multidimensional construct in which (i) proactiveness, (ii) innovativeness, (iii) risk taking, (iv) competitive aggressiveness, and (v) autonomy are treated as independent behavioural dimensions. Moreover, Covin and Lumpkin (2011) noted that these two concepts should be considered as different and separate perspectives, yet not competitive ones. However, most researchers apply the three-dimensional concept of EO (Table 2).

Table 2. The construct of EO

\begin{tabular}{|c|l|l|}
\hline No. & Basic Dimensions & \multicolumn{1}{c|}{ Composite Qualities } \\
\hline \multicolumn{2}{|c|}{ Three-dimensional Construct of EO } \\
\hline 1 & Proactiveness & $\begin{array}{l}- \text { predicting future market changes (Rauch et al., 2009) } \\
- \text { opportunity creation vs. opportunity identification (Sundqvist, } \\
\text { Kylaheiko \& Kuivalainen, 2012; Covin \& Slevin, 1989) }\end{array}$ \\
\hline 2 & Innovativeness & $\begin{array}{l}- \text { openness to new ideas (Frishammar \& Horte, 2007) } \\
- \text { process and product creativity (Dess \& Lumpkin, 2005) } \\
- \text { pursuit of creative or novel solutions (Knight, 2001) }\end{array}$ \\
\hline 3 & Risk taking & $\begin{array}{l}- \text { decisions in uncertainty (Dess \& Lumplik, 2005) } \\
- \text { implementation of projects entailing significant chances of costly } \\
\text { failure (Davis et al., 1991; Khandwalla, 1977; Miller \& Friesen, 1984) }\end{array}$ \\
\hline 4 & $\begin{array}{l}\text { Competitive } \\
\text { aggressiveness }\end{array}$ & $\begin{array}{l}\text { Multi-dimensional Construct of EO } \\
- \text { competitive advantage over competitors (Dess \& Lumplin, 2005) }\end{array}$ \\
\hline 5 & Autonomy & $\begin{array}{l}- \text { independent human activities (Dess \& Lumplin, 2005) } \\
- \text { self-acting (Lumpkin \& Dess, 1996) }\end{array}$ \\
\hline
\end{tabular}

Source: Own study.

Most of the empirical research applies the EO scale proposed by Miller (1983) as well as Covin and Slevin (1989) measuring three dimensions of EO by nine items and using 7point Likert scale (Table 1).

While discussing the theoretical construct of Entrepreneurial Orientation based on three dimensions, it is worth noting that the strict requirement of exhibiting high levels of each dimension in order to be recognized as an EO firm was significantly relaxed. Kreiser et al. (2002) as well as Lumpkin and Dess (1996) found that various levels of the three dimensions can equally shape EO of a given firm.

\section{International Entrepreneurial Orientation in International Firms}

Covin and Miller (2014) hold that discussing the issue of international entrepreneurial orientation (IEO), it should be investigated with the relation to EO and IE. These definitional matters resulted in the in-depth study of the phenomenon of IEO by Covin and Miller (2014). EO has been one of the main research themes within entrepreneurship for more than three decades, while its usage in international business studies is much younger. Kuivalainen, Sundqvist and Servais (2007, p. 253) notice that "both home-country and an international entrepreneurial orientation (EO and IEO, correspondingly) could be seen as antecedents that explain growth strategy and performance differences in firms" in the international context. 
As one of the first researchers, Knight (1997) tried to explore EO of firms operating across different cultures. While defining IE, McDougall and Oviatt (2000) focused on three elements, namely (i) innovative, (ii) proactive and (iii) risk taking behaviours, which applied the concept of EO. Covin and Miller (2014) stress that more recent definitions focus less explicitly on EO (Table 4). Most of the authors believes that IEO makes use of the three-dimensional concept of EO (Dai, Maksimov, Gilbert \& Fernhaber, 2014; Etemad, 2015; Gupta \& Gupta, 2015) supplementing the international context of entrepreneurship and international business (Table 5).

\section{Table 4. A chronicle development of selected definitions of IEO}

IEO "reflects the firm's overall pro-activeness and aggressiveness in its pursuit of international markets"

(Knight, 2001, p. 159)

IEO reflects "the firm's overall innovativeness and proactiveness in the pursuit of international markets. It is associated with innovativeness, managerial vision and proactive competitive posture"

(Knight \& Cavusgil, 2004, p. 129)

IOE is "a set of attributes commonly acknowledged as helpful for overcoming obstacles in the internationalization process"

(Jones \& Coviello, 2005)

IOE "refers to the behavior elements of a global orientation and captures top management's propensity for risk taking, innovativeness, and proactiveness."

(Freeman \& Cavusgil, 2007, p. 3)

IOE is "a set of behaviors associated with the potential creation of value, which manifest themselves as proactive and innovative methods, risk taking activity, autonomous actions, and an emphasis on outperforming rivals, all variously aimed at discovering, enacting, evaluating, and exploiting opportunities across national borders."

(Sundqvist, Kylaheiko \& Kuivalainen, 2012, p. 205)

"IOE is not treated as a construct distinct from EO. Rather, 'international' is simply a context in which the EO phenomenon is explored."

(Covin \& Miller, 2013, p. 14)

Source: own study.

Knight (2001) is convinced that three-dimensional international entrepreneurial orientation is the major success factor determining the international performance of the firm (Figure 4). Strategic behaviour theory is especially important for a firm operating in international markets where various environmental parameters pose special challenges to the entering firm. Two additional factors supporting international performance of firms are (i) internationalisation preparation entailing market research conducting or resources commitment to international operations and (ii) technology acquisition enabling to acquire technologies that will augment the firm's ability to compete in international markets by implementing innovative products and behaviours.

International entrepreneurial culture (IEC) can be considered as a parallel and complimentary concept to IEO. Dimitratos and Plakoyiannaki (2003) suggest that an international entrepreneurial culture embodies six dimensions, namely (i) the market orientation towards international activities, (ii) the learning orientation focused foreign 
markets and the alertness to opportunities that exist in these markets, (iii) the innovation propensity, (iv) the risk attitudes in pursuit of new opportunities in foreign markets, (v) the networking orientation, (vi) the motivation orientation in order to explore and exploit opportunities in foreign markets. Zahra (2005) claims it would instructive to apply these six dimensions while explaining international new ventures or born globals.

Table 5. The three-dimensional construct of IEO

\begin{tabular}{|c|c|}
\hline Dimensions & Composite Qualities \\
\hline Proactiveness & $\begin{array}{l}\text { - aggressive positioning relative to competitors in pursuit of the firms } \\
\text { international market objectives (Knight, 2001). } \\
\text { - capitalising on new and existing international business opportunities } \\
\text { (Wiklund \& Shepherd, 2005). }\end{array}$ \\
\hline Innovativeness & $\begin{array}{l}\text { - a firm's tendency to enter into experimentation, support new } \\
\text { international ideas and depart from established practices (Lumpkin \& } \\
\text { Dess, 1996; Miller, 1983; Wiklund \& Shepherd, 2005). } \\
\text { - the development or enhancement of products and services (Knight, 2001) }\end{array}$ \\
\hline Risk taking & $\begin{array}{l}\text { - willingness of the international entrepreneur to make investments and } \\
\text { commit resources to projects that have uncertain outcomes or unusually } \\
\text { high profits and/or losses (Lumpkin \& Dess, 1996; Wiklund \& Shepherd, } \\
\text { 2005) }\end{array}$ \\
\hline
\end{tabular}

Source: own study based on Glavas \& Mathews (2014, p. 230).

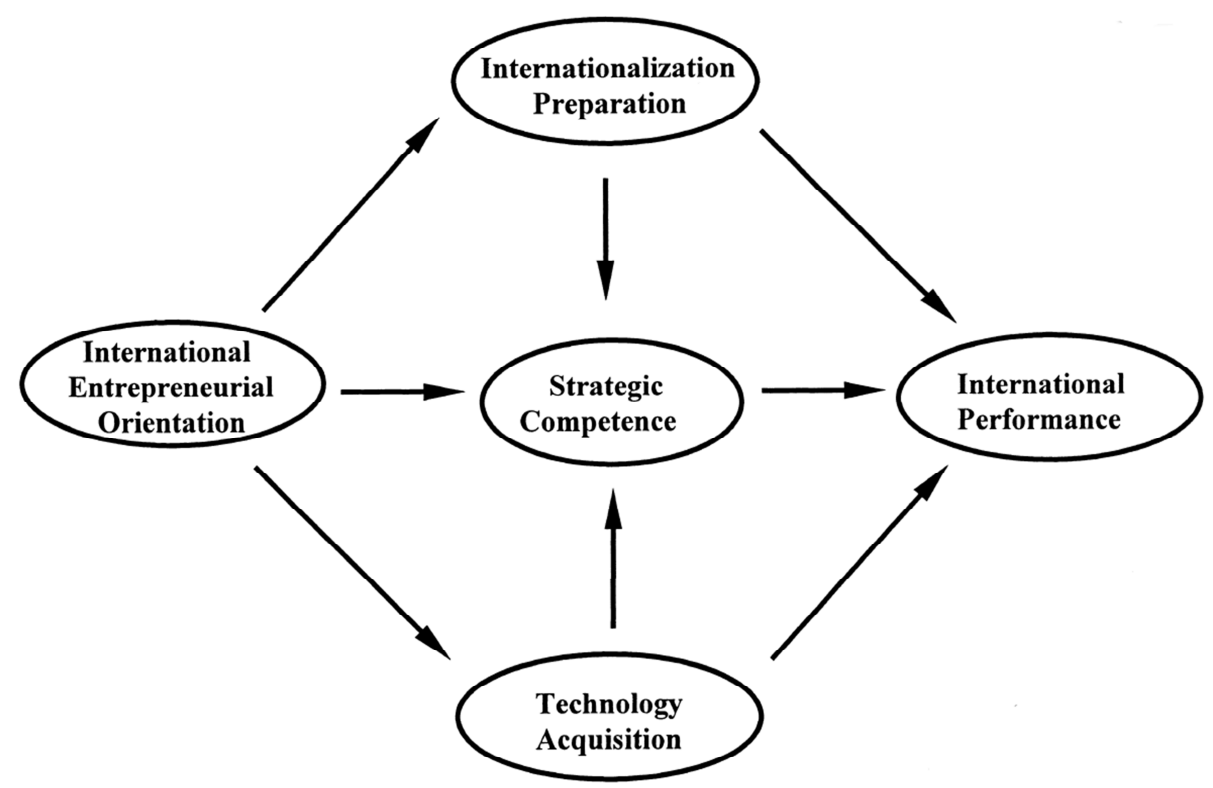

Figure 5. Entrepreneurial orientation as a key performance antecedent of the firm-level internationalisation

Source: Knight (2001, p. 160). 
The above theoretical developments suggest building a three-step process of international entrepreneurship (Figure 5). International entrepreneurial orientation makes its first and major step, being the quintessence of entrepreneurial internationalisation (McDougall \& Oviatt, 2000). The most important in the entrepreneurial process is the entrepreneurial decision making process itself, especially the decision to enter new international markets or to enhance the presence into international markets, which can be considered as innovation. Strategic international decisions usually focus on three patters such as (i) scope, (ii) scale or extent and (iii) time or pace/speed (Zahra \& George, 2002; Kuivalainen, Sundqvist \& Saarenko, 2012; Wach, 2014c). Knight (2001, p. 165) notices that IEO "appears to drive key strategic initiatives intended to enhance organizational performance".

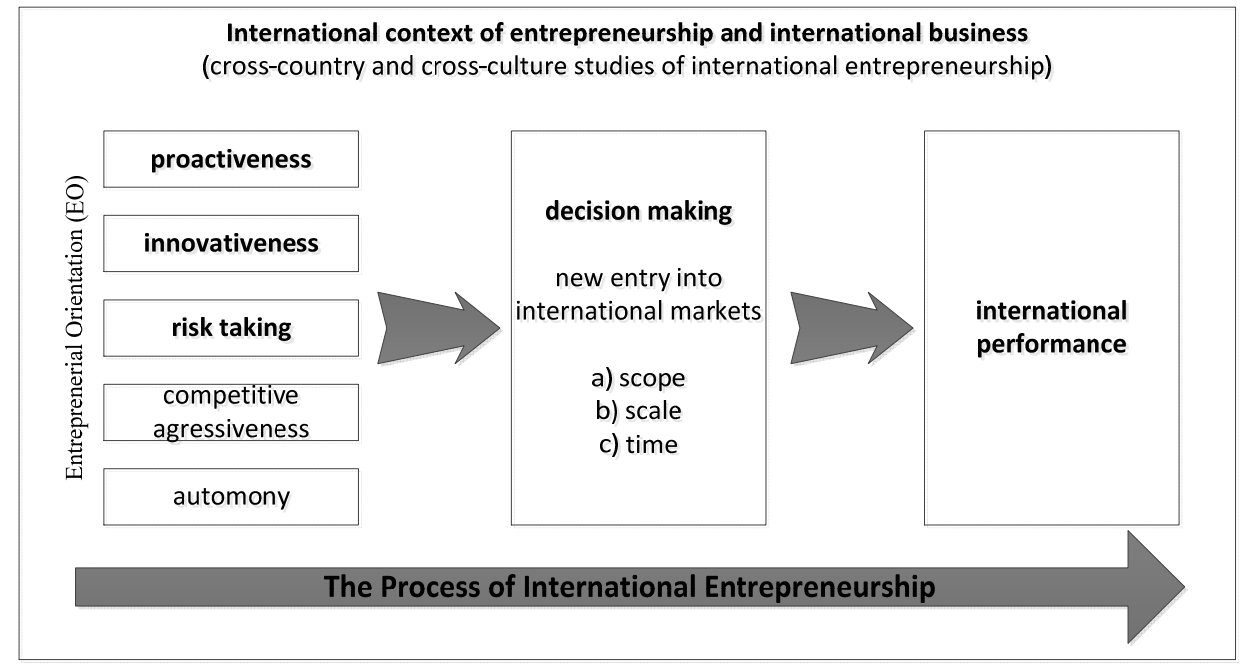

Figure 6. International entrepreneurship from the process-and-contextuality perspective Source: own study.

\section{CONCLUSIONS}

International entrepreneurship focuses on the entrepreneur as well as on innovation and entrepreneurial processes concerning recognition and exploitation of international opportunities in the context of institutional environment and entrepreneurship culture (Bruton, Lau \& Obloj, 2014). Therefore, international entrepreneurial orientation "can be meaningfully extended into the field of IE as a way of examining and explaining the cross-border internationalisation of firms" (Glavas \& Mathews, 2014, p. 230). It seems that creating a solid and unique methodology for international entrepreneurship is essential to recognise international entrepreneurship as a separate research discipline, as is true currently in the case of international business. Taking into account the interdisciplinary character of entrepreneurship, it is possible that international entrepreneurship will fully become 'a hub and a spoke' (Mtigwe, 2006, p. 19) and a binder for all internationalisation theories and approaches constituting the base for the 
integrative models. While summarising the issue of international entrepreneurial orientation, Glavas and Mathews (2014, p. 230) stress that:

- IEO is a multi-dimensional concept (Covin \& Slevin, 1991),

- IEO can be considered both an individual and firm-level construct (Knight, 2001),

- IEO enables business to identify and exploit internationalisation opportunities (Mostafa, Wheeler \& Jones, 2006; Slevin \& Terjesen, 2011),

- IEO reflects the firms overall proactiveness and aggressiveness in its pursuit of international markets (Knight, 2001),

- IEO involves taking advantage of international market offerings and taking risks in international environments (Jantunen, Puumalainen, Saarenketo \& Kylaheiko, 2005; Wang, 2008).

\section{REFERENCES}

Autio, E., Sapienza, H.J., \& Almeida, J.G. (2000). Effects of age at entry, knowledge intensity, and imitability on international growth. Academy of Management Journal, 43(5), 909-924.

Andersson, S., \& Florén, H. (2008). Exploring managerial behavior in small international firms. Journal of Small Business and Enterprise Development, 15(1), 31-50.

Antoncic, B., \& Hisrich, R.D. (2001). Intrapreneurship: Construct refinement and crosscultural validation. Journal of Business Venturing, 16(5), 495-527.

Babbie, E. (2012). The Practice of Social Research. 13th ed., Belmont, CA: Wadsworth Cengage Learning.

Basso, O., Fayolle, A., \& Bouchard, V. (2009). Entrepreneurial orientation: The making of a concept. Entrepreneurship and Innovation, 10(4), 313-321.

Bruton, G.D., Lau, C-M., \& Obloj, K. (2014). Institutions, resources and firm strategies: a comparative analysis of entrepreneurial firms in three transitional economies. European Journal of International Management, 8(6), 697-720.

Claar, V., Frey, R., Szarucki, M., \& TenHaken, V.R. (2012). Hope for the East: Entrepreneurial Attitudes of MBA Students in Two Transition Economies relative to those in the USA. Business Excellence, 5(3), 220-237.

Collis, J., \& Hussey, R. (2009). Business Research: A Practical Guide for Undergraduate \& Postgraduate Students. 3rd ed., London: Palgrave Macmillan.

Coviello, N.E., McDougall, P.P., \& Oviatt, B.M. (2011). The emergence, advance and future of international entrepreneurship research - An introduction to the special forum. Journal of Business Venturing, 26(6), 625-631.

Covin, J., \& Slevin, D. (1989). Strategic management of small firms in hostile and benign environments. Strategic Management Journal, 10(1), 75-87.

Covin, J.G, \& Lumpkin, G.T., (2011). Entrepreneurial Orientation Theory and Research: Reflections on a Needed Construct. Entrepreneurship Theory and Practice, 35(5), 855-872.

Covin, J.G., \& Miller, D. (2014). International entrepreneurial orientation: conceptual considerations, research themes, measurement issues, and future research directions. Entrepreneurship Theory and Practice, 38(1), 11-44. doi: 10.1111/etap.12027.

Covin, J.G., \& Slevin, D.P. (1991). A conceptual model of entrepreneurship as firm behavior. Entrepreneurship Theory and Practice, 16(1), 7-25. 
Dai, L., Maksimov, V., Gilbert, B.A., \& Fernhaber, S.A. (2014). Entrepreneurial orientation and international scope: The differential roles of innovativeness, proactiveness, and risk-taking. Journal of Business Venturing, 29(4), 511-524.

Daszkiewicz, N. (2014a). Internacjonalizacja polskich przedsiębiorstw rodzinnych z perspektywy przedsiębiorczości międzynarodowej. Przedsiębiorczość i Zarzq̨dzanie, XV(7[1]), 243-251.

Daszkiewicz, N. (2014b). Przedsiębiorczość międzynarodowa jako nowy obszar badań w teorii internacjonalizacji. In: A. Budnikowski, A. Kuźnar (Ed.), Nowe procesy w gospodarce światowej: wnioski dla Polski (pp. 207-219). Warszawa: Oficyna Wydawnicza Szkoły Głównej Handlowej.

Davis, D., Morris, M., \& Allen, J. (1991). Perceived environmental turbulence and its effect on selected entrepreneurship, marketing, and organizational characteristics in industrial firms. Journal of the Academy of Marketing Science, 19 (1), 43-51.

Dess, G.G., \& Lumpkin, G.T. (2005). The role of entrepreneurial orientation in stimulating corporate entrepreneurship: research briefs. Academy of Management Executive , 19(1), 147-156.

Dimitratos, P., \& Plakoyiannaki, E. (2003). Theoretical foundations of an international entrepreneurial culture. Journal of International Entrepreneurship, 1(2), 187-215.

Etemad, H. (2015). Entrepreneurial Orientation - Performance Relationship in the International Context. Journal of International Entrepreneurship, 13(1), 1-6.

Fisher, C. et al. (2010). Researching and Writing a Dissertation. 3rd edition. Harlow: Prentice Hall.

Freeman, S., \& Cavusgil, S.T. (2007). Toward a typology of commitment states among managers of bornglobal firms: A study of accelerated internationalization. Journal of International Marketing, 15(4), 1-40.

Frishammar, J., \& Andersson, S. (2009). The overestimated role of strategic orientations for international performance in smaller firms. Journal of International Entrepreneurship, 7(1), 5777.

Fudaliński, J. (2014). Dysfunctions of NPOs and NGOs in Poland in the Global Context: Some International Comparisons. Entrepreneurial Business and Economics Review, 2(1), 81-94. doi: 10.15678/EBER.2014.020107.

Gaweł, A. (2008). Entrepreneurship - A Theoretical Approach (chapter 1). In: M. Rekowski (Ed.), Entrepreneurial Tissue and Regional Economy: Case Studies of Selected Polish and Spanish Regions (pp. 11-25). Poznań: The Poznan University of Economics Publishing House.

Gaweł, A. (2013). Proces przedsiębiorczy: tworzenie nowych przedsiębiorstw. Warszawa: Difin.

Gelbuda, M., Meyer, K.E., Delios, A. (2008). International business and institutional development in Central and Eastern Europe. Journal of International Management, 14(1), 1-11. doi: 10.1016/j.intman.2007.05.011.

Glavas, Ch., \& Mathews, Sh. (2014). How international entrepreneurship characteristics influence Internet capabilities for the international business processes of the firm. International Business Review, 23(1), 228-245. doi: 10.1016/j.ibusrev.2013.04.001.

Gupta, V.K, \& Gupta, A. (2015). Relationship between Entrepreneurial Orientation and Firm Performance in Large Organizations over Time. Journal of International Entrepreneurship, 13(1), 7-27.

Jantunen, A., Puumalainen, K., Saarenketo, S., \& Kylaheiko, K. (2005). Entrepreneurial orientation, dynamic capabilities and international performance. Journal of International Entrepreneurship, $3(3), 232-243$.

Jones, M., \& Coviello, N.E. (2005). Internationalization: Conceptualising an Entrepreneurial Process of Behaviour in Time. Journal of International Business Studies, 36(3), 284-303.

Khandwalla, P. (1977). The Design of Organizations. Harcourt Brace Jovanovich, New York. 
Knight, G.A. (1997). Emerging paradigm for international marketing: The born-global firm. Doctoral dissertation. East Lansign, MI: Michigan State University.

Knight, G.A. (2001). Entrepreneurship and strategy in the international SME. Journal of International Management, 7(3), 155-171.

Knight, G.A., \& Cavusgil, S.T. (2004). Innovation, organizational capabilities, and the born global firm. Journal of International Business Studies, 35(2), 124-141.

Knight, G.A. (2001). Entrepreneurship and strategy in the international SME. Journal of International Management, 7(3), 155-71.

Kuivalainen, O., Sundqvist, S. \& Saarenko, S. (2012). Internationalization Patterns of Small and Medium-sized Enterprises. International Marketing Review, 29(5), 448-465.

Kuivalainen, O., Sundqvist, S., \& Servais, P. (2007). Firms' degree of born-globalness, international entrepreneurial orientation and expert performance. Journal of World Business, 42(3), 253267.

Lumpkin, G.T., \& Dess, G.G. (1996). Clarifying the entrepreneurial orientation construct and linking it to performance. Academy of Management Review, 21(1), 135-172.

Lumpkin, G.T., \& Dess, G.G. (2001). Linking two dimensions of entrepreneurial orientation to firm performance: The moderating role of environment and industry life cycle. Journal of Business Venturing, 16(5), 429-451.

McDougall, P.P., \& Ovatt, B.M. (2000). International entrepreneurship: The intersection of two research paths. Academy of Management Journal, 43(5), 902-909.

McDougall-Covin, P., Jones, M.V. \& Serapio, M.G. (2014). High-Potential Concepts, Phenomena, and Theories for the Advancement of Entrepreneurship Research. Entrepreneurship Theory and Practice, 38(1), 1-10.

Meyer, K.E., \& Gelbuda, M. (2006). Process perspectives in international business research in CEE. Management International Review, 46(2), 143-164. doi: 10.1007/s11575-006-0042-5.

Miller, D. (1983). The correlates of entrepreneurship in three types of firms. Management Science, 29(7), 770-791.

Miller, D., \& Friesen, P. (1984). Organizations: A Quantum View. Englewood Cliffs: Prentice-Hall, NJ.

Mintzberg, H. (1973). Strategy-making in three modes. California Management Review, 16(2), 4453.

Mostafa, R.H.A., Wheeler, C., \& Jones, M.V. (2006). Entrepreneurial orientation, commitment to the Internet and export performance in small and medium sized exporting firms. Journal of International Entrepreneurship, 3(1), 291-302.

Mtigwe, B. (2006). Theoretical Milestones in International Business: The Journey to International Entrepreneurship Theory. Journal of International Entrepreneurship, 4(1), 5-25.

Obloj, K., Weinstein, M., \& Zhang, Sh. (2013). Self-Limiting Dominant Logic: An Exploratory Study of Chinese Entrepreneurial Firms. Journal of East-West Business, 19(4), 291-316. doi: 10.1080/10669868.2013.847888.

Oviatt B.M., \& McDougall, P.P. (1994). Towards a Theory of International New Ventures. Journal of International Business Studies, 25(1), 44-64.

Oviatt, B.M., \& McDougall, P.P. (2005). Defining international entrepreneurship and modeling the speed of internationalization. Entrepreneurship Theory and Practice, 29(5), 537-553.

Oyson, M., \& Whittaker, D.W. (2010). An Opportunity-Based Approach to International Entrepreneurship: Pursuing Opportunities Internationally through Prospection. Proceedings of the 18th Annual High Technology Small Firms Conference, May 27-28, 2010, The Netherlands. 
Rauch, A., Wiklund, J., Lumpkin, G.T., \& Frese, M. (2009). Entrepreneurial orientation and business performance: An assessment of past research and suggestions for the future. Entrepreneurship Theory and Practice, 33(3), 761-787.

Ruzzier M., Hisrich, R.D., \& Antoncic, B. (2006). SME Internationalization Research: Past, Present, and Future. Journal of Small Business and Enterprise Development, 13(4), 476-497.

Slevin, D., \& Terjesen, P.S.A. (2011). Entrepreneurial orientation: Reviewing three papers and implications for further theoretical and methodological development. Entrepreneurship Theory and Practice, 35(5), 973-987.

Sundqvist, S., Kylaheiko, K., \& Kuivalainen, O. (2012). Kirznerian and Schumpeterian entrepreneurialoriented behavior in turbulent export markets. International Marketing Review, 29(2), 203-219.

Volkmann, C.K., Tokarski, K.O., \& Grunhagen, M. (2010). Entrepreneurship in a European Perspective. Berlin: Gabler Verlag.

Wach, K. (2012). Europeizacja małych i średnich przedsiębiorstw: rozwój przez umiędzynarodowienie. Warszawa: PWN.

Wach, K. (2014a). Internationalisation and Globalisation as a Wider Context of Europeanisation from Micro and Macroeconomic Perspective. Horyzonty Polityki, 5(10), 11-30.

Wach, K. (2014b). Przedsiębiorczość międzynarodowa jako nowy kierunek badań w obrębie teorii internacjonalizacji przedsiębiorstwa (Chapter 28). In S. Wydymus \& M. Maciejewski (eds), Tradycyjne $i$ nowe kierunki rozwoju handlu międzynarodowego (pp. 433-446). Warszawa: CeDeWu.

Wach, K. (2014c). Theoretical Framework of the Firm-Level Internationalisation in Business Studies (chapter 1). In: A. Duréndez \& K. Wach (Eds.), Patterns of Business Internationalisation in Visegrad Countries - In Search for Regional Specifics (pp. 13-30). Cartagena: Universidad Politécnica de Cartagena.

Wach, K. (2015). Impact of Cultural and Social Norms on Entrepreneurship in the EU: Cross-Country Evidence based on GEM Survey Results. Zarzqdzanie $w$ Kulturze, 16(1), 15-29. doi: 10.4467/20843976ZK.15.002.3037

Wang, C.L. (2008). Entrepreneurial orientation, learning orientation, and firm performance. Entrepreneurship Theory and Practice, 32(4), 635-657.

Wiklund, J., \& Shepherd, D., (2005). Entrepreneurial orientation and small business performance: a configurational approach. Journal of Business Venturing, 20(1), 71-91.

Zahra, S.A. (1996). Governance, ownership, and corporate entrepreneurship: the moderating impact of industry technical opportunities. The Academy of Management Journal, 39(6), 17131735. doi: $10.2307 / 257076$.

Zucchella, A., \& Scabini, P. (2007). International Entrepreneurship - Theoretical foundations and Practice. New York: Palgrave Macmillan.

Żur, A. (2013). Entrepreneurial Orientation and Firm Performance - Challenges for Research and Practice. Entrepreneurial Business and Economics Review, 1(2), 7-28. doi: 10.15678/EBER.2013.010202.

Żur, A., \& Wałęga, A. (2015). Routines do matter: role of internal communication in firm-level entrepreneurship. Baltic Journal of Management, 10(1), 119-139. doi: 10.1108/BJM-11-20130166. 


\section{Author}

\section{Krzysztof Wach}

Associate Professor of the Cracow University of Economics (Poland). Habilitated doctor of economics (DEcon), PhD in management, specialist in international entrepreneurship, author of several books and over 150 scientific articles, editor-in-chief of the scientific quarterly 'Entrepreneurial Business and Economics Review', member of editorial boards of several scientific journals, including 'Business Excellence' (Croatia), 'Studia Negtia' (Romania), 'Entrepreneurship - Education' (Poland); in the years 2012-2014 an OECD and the European Commission national expert for entrepreneurship, participant of various international education and research projects (e.g. Jean Monnet, Atlantis, International Visegrad Fund IVF, Central European Initiative CEI), visiting professor in various American and European universities, including Grand Valley State University (Grand Rapids, USA), Roosevelt University (Chicago, USA), University of Detroit Mercy (Detroit, USA), Loyola University Chicago (Chicago, USA), Northumbria University (Newcastle, UK), University College London (UK), Technical University of Cartagena (Cartagena, Spain).

\section{Correspondence to:}

Prof. UEK dr hab. Krzysztof Wach

Cracow University of Economics

Faculty of Economics and International Relations

Department of Entrepreneurship and Innovation

31-510 Kraków, ul. Rakowicka 27, Poland

wachk@uek.krakow.pl

\section{Acknowledgements and Financial Disclosure}

The article came into being within the statutory research project no. 121/WE$\mathrm{KPI} / 03 / 2014 / \mathrm{S} / 4317$ entitled "Entrepreneurial and Innovation Processes as Catalyst and Stabilizers of Business Internationalisation" coordinated by K. Wach and financed by the Ministry of Science and Higher Education of the Republic of Poland with the funds allocated to development of research potential of the Faculty of Economics and International Relations of the Cracow University of Economics.

\section{Copyright and License}

This article is published under the terms of the Creative Commons Attribution - NonCommercial - NoDerivs (CC BY-NC-ND 3.0) License http://creativecommons.org/licenses/by-nc-nd/3.0/ 